\title{
Comparative analysis of MODIS, MISR, and AERONET climatology over the Middle East and North Africa
}

\author{
Ashraf Farahat \\ Department of Physics, King Fahd University of Petroleum and Minerals, Dhahran 31261, Saudi Arabia \\ Correspondence: Ashraf Farahat (farahata@kfupm.edu.sa)
}

Received: 4 July 2018 - Discussion started: 23 July 2018

Revised: 1 January 2019 - Accepted: 9 January 2019 - Published: 29 January 2019

\begin{abstract}
Comparative analysis of Multi-angle Imaging SpectroRadiometer (MISR), Moderate Resolution Imaging Spectroradiometer (MODIS), and Aerosol Robotic Network (AERONET) aerosol optical depth (AOD) products is performed over seven AERONET stations located in the Middle East and North Africa for the period of 2000 2015. Sites are categorized into dust, biomass burning, and mixed aerosol conditions. MISR and MODIS AOD agree during high-dust seasons but MODIS tends to underestimate AOD during low-dust seasons. Over dust-dominated sites, MODIS/Terra AODs indicate a negative trend over time, while MODIS/Aqua, MISR, and AERONET depict a positive trend. A deviation between MODIS/Aqua and MODIS/Terra was observed regardless of the geographic location and data sampling. The performance of MODIS is similar over the entire region with $\sim 64 \%$ of AOD within the $\Delta \tau= \pm 0.05 \pm 0.15 \tau_{\mathrm{AERO}}$ confidence range. MISR AOD retrievals fall within $84 \%$ of the same confidence range for all sites examined here. Both MISR and MODIS capture aerosol climatology; however few cases were observed where one of the two sensors better captures the climatology over a certain location or AOD range than the other sensor. AERONET Level 2.0 version 3, MODIS Collection 6.1, and MISR V23 data have been used in analyzing the results presented in this study.
\end{abstract}

\section{Introduction}

The Middle East and North Africa host the largest dust source in the world, the Sahara desert in North Africa that may be responsible for up to $18 \%$ of global dust emission (Todd et al., 2007; Bou Karam et al., 2010; Schepanski et al.,
2016). The vast $650000 \mathrm{~km}^{2}$ Rub' al Khali (Empty Quarter) sand desert is a major source of frequent dust outbreaks and severe dust storms that have a major effect on human activity in the Arabian Peninsula (Böer, 1997; Elagib and Addin, 1997; Farahat et al., 2015).

Air quality over the Arabian Peninsula has received significant attention during the past 15 years due to unprecedented overall economic growth and a booming oil and gas industry; however, air pollution studies are still far from complete. Frequently blowing dust storms play a significant role in pollutant transport over the Arabian Peninsula, and major environmental pollution events such as burning of Kuwait oil fields during the 1991 Gulf War resulted in a large environmental impact on the Arabian Gulf area (Sadiq and McCain, 1993; Farahat, 2016).

Aerosol optical depth (AOD; also called aerosol optical thickness, AOT) as a parameter indicates the extinction of a beam of radiation as it passes through a layer of atmosphere that contains aerosols. Both satellites and ground-based instruments can be used to measure AOD in the atmosphere, but within the same temporal coordinates and geographic location different instruments could generate different retrievals (Kahn et al., 2007; Kokhanovsky et al., 2007; Liu and Mishchenko, 2008; Mishchenko et al., 2009).

Since the turn of the 21st century, an upward trend of remotely sensed and ground-based AOD and air pollutants was observed over the Middle East and North Africa (El-Askary et al., 2009; Ansmann et al., 2011; Yu et al., 2013, 2015; Chin et al., 2014; Farahat et al., 2016a, b; Solomos et al., 2017). This positive trend is attributed to the increase in the Middle Eastern dust activity (Hsu et al., 2012) due to changes in wind speed and soil moisture (Ginoux et al., 2001; Kim et al., 2013). Yu et al. (2015) concluded that the persistent La Niña 
conditions (Hoell et al., 2013) have caused an increase in Saudi Arabian dust activity during 2008-2012. Energy subsidies also encourage energy overconsumption in the Middle East and North Africa with little incentive to adopt cleaner technology. The lack of strict environmental regulations has resulted in exacerbated urban air pollution.

During the last two decades, a large number of satellites, ground stations, and computational models contributed to build global and regional maps for the temporal and spatial aerosol distributions. While ground-based stations and field measurements can identify aerosols properties over specific geographic locations, the spare and non-continuous data from ground-based sensors scattered over the Middle East and North Africa are not sufficient to provide information on spatial and temporal trends of particulate pollution. On the other hand, satellites imagery could provide a significant source of data mapping over larger areas.

For its wide spatial and temporal data availability spaceborne sensors are important sources to understand aerosol characteristics and transport; however low sensitivity to particle type under some physical conditions, high surface reflectivity, persistent cloud, and generally low aerosol optical depth could limit satellite data application in characterizing properties of airborne particles, especially in the Middle East.

In order to evaluate the efficiency of space-borne sensors in representing ground observations recorded by AERONET (Aerosol Robotic Network) stations, we have performed detailed statistical inter-comparison analysis between satellite AOD products and AERONET for seven stations in the Middle East and North Africa (Fig. 1) representative for dust, biomass burning, and mixed aerosol conditions (Dubovik and King, 2000; Dubovik et al., 2002, 2006; Holben et al., 2001; Derimian et al., 2006; Basart et al., 2009; Eck et al., 2010; Marey et al., 2010; Abdi et al., 2012). Previously we analyzed these seven AERONET stations to understand particle categorization and absorption properties (Farahat et al., 2016b), and the current study extends the analysis to the satellite datasets.

In the first part of this article, we validated Multi-angle Imaging SpectroRadiometer (MISR) and MODIS retrievals against collocated AERONET observations. We also assessed the consistency in aerosol trends between space-borne sensors and ground-based data.

In the second part, we evaluated representativeness of satellite-derived aerosol climatology over the study region from the long-term AERONET data for MISR and MODIS AOD products. It is especially relevant for the MISR instrument, as its sampling is limited by once-per-week observations of the same region from the two overlapping paths. MODIS provides nearly daily observations for the same geographic location; however, the quality of the product diminishes over the bright targets, potentially affecting MODISderived aerosol climatology.

The collocated MISR, MODIS, and AERONET data were obtained at the Giovanni Multi-sensor Aerosol Products

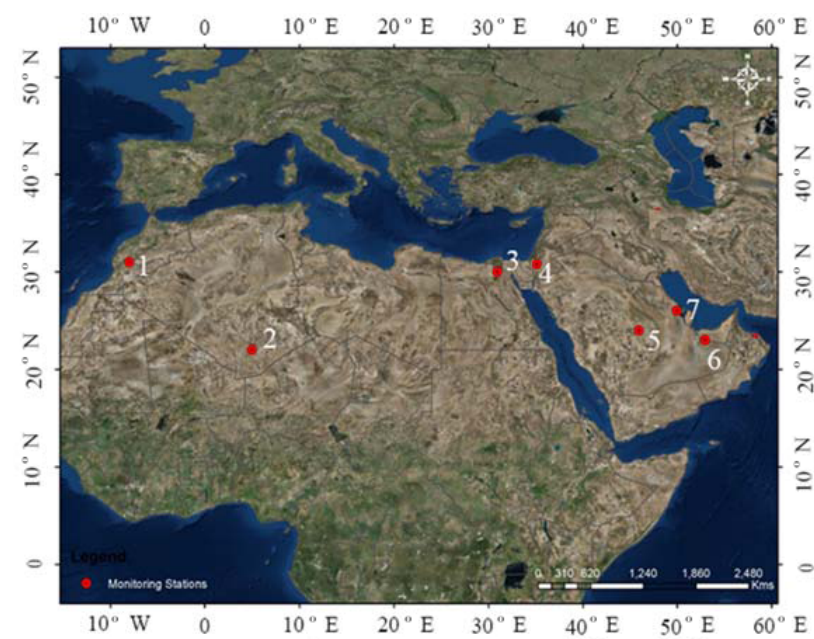

Figure 1. Location of the AERONET stations over North Africa and the Middle East. The numbers on the map indicate the site location as follows. 1: Saada, 2: Tamanrasset_INM, 3: Cairo, 4: Sde Boker, 5: Solar Village, 6: Mezaira, 7: Bahrain.

Sampling System (MAPSS) website (http://giovanni.gsfc. nasa.gov/mapss.html, last access: 1 December 2018).

\section{Materials and methods}

\subsection{MISR}

The Multi-angle Imaging SpectroRadiometer (MISR) instrument measures tropospheric aerosol characteristics through the acquisition of global multi-angle imagery on the daylight side of Earth. MISR applies nine charge-coupled devices (CCDs), each with four independent line arrays positioned at nine view angles spread out at nadir, 26.1, 45.6, 60.0 , and $70.5^{\circ}$. In each of the nine MISR cameras, images are obtained from reflected and scattered sunlight in four bands - blue, green, red, and near-infrared - with a center wavelength value of $446,558,672$, and $867 \mathrm{~nm}$ respectively. The combination of viewing cameras and spectral wavelengths enables MISR to retrieve aerosols AOD over high-reflectivity surfaces like deserts.

In this study, we use Level 2 (version 0023) AOD at $558 \mathrm{~nm}$ (green band) measured by the MISR instrument with a $17.6 \mathrm{~km}$ resolution aboard the Terra satellite. MISR Level 2 aerosol retrievals use only data that pass angle-toangle smoothness and spatial correlation tests (Martonchik et al., 2002), as well as stereoscopically derived cloud masks and adaptive cloud-screening brightness thresholds (Zhao and Girolamo, 2004).

\subsection{MODIS}

The Moderate Resolution Imaging Spectroradiometer (MODIS) is a payload instrument on board the Terra 
and Aqua satellites. Terra and Aqua orbit around the Earth from north to south and south to north across the Equator during the morning and afternoon respectively (Kaufman et al., 1997). Terra MODIS and Aqua MODIS provide nearly daily coverage of the Earth's surface and atmosphere in 36 wavelength bands, ranging from 0.412 to $41.2 \mu \mathrm{m}$, with spatial resolutions of $250 \mathrm{~m}$ (bands 1-2), $500 \mathrm{~m}$ (bands 3-7), and $1000 \mathrm{~m}$ (bands $8-36)$. Located near polar orbit $(705 \mathrm{~km})$, MODIS has swath dimensions of $2330 \mathrm{~km} \times 10 \mathrm{~km}$ and a scan rate of $20.3 \mathrm{rpm}$. With its high radiometric sensitivity and swath resolution MODIS retrievals provide information about aerosol optical and physical characteristics. MODIS uses 14 spectral band radiance values to evaluate atmospheric contamination and determine whether scenes are affected by cloud shadow (Ackerman et al., 1998).

The Deep Blue (DB) algorithm is a NASA-developed algorithm to calculate AOD over land using MODIS data. By measuring contrast between aerosols and surface features, DB retrieves AOD. Over bright land, Deep Blue uses 0.412, 0.470 , and $0.479 \mu \mathrm{m}$ for AOD retrievals. Over water, the DB algorithm is not used, but the Dark Target (DT) algorithm is used instead.

The MODIS DT algorithm is designed for aerosol retrieval from MODIS observations, over dark land surfaces (low values of surface reflectance) (e.g., dark soil and vegetated regions) in parts of the visible (VIS, 0.47 and $0.65 \mu \mathrm{m})$ and shortwave infrared (SWIR, $2.1 \mu \mathrm{m}$ ) spectrum (Kaufman et al., 1997). The Level 2 Collection 6 (C006) data of the algorithm are used to retrieve MODIS aerosols' time series data. Levy et al. (2010) reported that the Dark Target algorithm AOD at $550 \mathrm{~nm}$ measurement for Collection 5 (C005) includes uncertainty of $\pm(0.05 \tau+0.03)$ and $\pm(0.15 \tau+0.05)$ over ocean and land respectively. This uncertainty is caused by uncertainties in computing cloud masking, surface reflectance, aerosol model type (e.g., single-scattering albedo), pixels selections, and instrument calibration.

Both DB and DT algorithms have been used in this study. DB data were used over land, while DT retrievals were used over water. For regions like Bahrain where a large water body surrounds land, a combined DB and DT algorithm for land and ocean has been used. This is because the MODIS matched ground-based AERONET station in Bahrain (described in Sect. 2.3 and Table 1) is located less than $2 \mathrm{~km}$ from the coastline. This makes MODIS combine retrievals for both land and water over this region. Data are available at https://giovanni.gsfc.nasa.gov/giovanni (last access: 5 December 2018).

\subsection{AERONET}

The Aerosol Robotic Network (AERONET) (Holben et al., 1998,2001 ) is a ground-based remote sensing aerosols network that provides long-term data related to aerosol optical, microphysical, and radiative properties. With over 700 global stations, the AERONET data are widely used in validating
Table 1. Geographic location of the AERONET sites used in this study.

\begin{tabular}{lcc}
\hline Location name & Longitude/latitude & $\begin{array}{c}\text { Measurement } \\
\text { period }\end{array}$ \\
\hline Solar Village & $24.907^{\circ} \mathrm{N} / 46.397^{\circ} \mathrm{E}$ & $2000-2015$ \\
Mezaira & $23.105^{\circ} \mathrm{N} / 53.755^{\circ} \mathrm{E}$ & $2004-2015$ \\
Bahrain & $26.208^{\circ} \mathrm{N} / 50.609^{\circ} \mathrm{E}$ & $2000-2006$ \\
Saada & $31.626^{\circ} \mathrm{N} / 8.156^{\circ} \mathrm{W}$ & $2003-2015$ \\
Taman & $22.790^{\circ} \mathrm{N} / 5.530^{\circ} \mathrm{E}$ & $2000-2015$ \\
Cairo (EMA_2) & $30.081^{\circ} \mathrm{N} / 31.290^{\circ} \mathrm{E}$ & $2010-2017$ \\
Sde Boker & $30.855^{\circ} \mathrm{N} / 34.782^{\circ} \mathrm{E}$ & $2000-2015$ \\
\hline
\end{tabular}

satellite retrievals (Chu et al., 1998; Higurashi and Nakjima, 1999).

The sun photometers used by AERONET measure spectral direct-beam solar radiation, as well as directional diffuse radiation in the solar almucantar. The former are used to determine columnar spectral AOD and water vapor, provided at a temporal resolution of approximately $10-15 \mathrm{~min}$ (Sayer et al., 2014). AERONET direct-sun AOD has a typical uncertainty of 0.01-0.02 (Holben et al., 1998) and is provided at multiple wavelengths at $340,380,440,500,675,950$, and $1020 \mathrm{~nm}$.

Seven AERONET sites were selected for satellite validation in this study (Table 1). The sites were selected based on their geographic locations to represent aerosol characteristics over North Africa and the Middle East (Farahat et al., 2016a, b). A record of long-term data collection was another factor in the selection process.

\section{Data-matching approach}

Multi-sensor data matching requires using only compatible data to eliminate uncertainties associated with cloud shadow and spatial and temporal retrievals produced by different instruments (Liu and Mishchenko, 2008; Mishchenko et al., 2009).

The comparison of MISR and MODIS products against AERONET is performed to evaluate the satellites' retrieval over individual North Africa and Middle East sites (see Table 1). There is only a small number of AERONET measurements that are perfectly collocated with MODIS and MISR. One way to work with this lack-of-compatibility problem is to compare satellite measurements near a certain AERONET site and compare AERONET measurements nearly synchronized with the satellite overpass time (Sioris et al., 2017). Another reasonable strategy is to average all satellite measurements with a certain distance of an AERONET location and average all AERONET measurements within a certain time range (Mishchenko et al., 2010). The results presented in this paper are based on the second approach as it compares average spatial satellite measurements with average temporal AERONET measurements. We implemented the Basart 
et al. (2009) approach in using a spatial and temporal threshold of $50 \mathrm{~km}$ and $30 \mathrm{~min}$ for MISR, MODIS, and AERONET data matching.

We use the Giovanni Multi-sensor Aerosol Products Sampling System (http://giovanni.gsfc.nasa.gov/aerostat/, last access: 10 December 2018) for the data inter-comparison as aerosols products are averaged from measurements that are within a radius of $\sim 27.5 \mathrm{~km}$ from the AERONET station and within $30 \mathrm{~min}$ of each satellite flyover over this location. These data are represented in the article by MISR and MODIS "matched AERONET data".

The AOD products at the selected station are represented by "all data". AERONET station all data are obtained through the AERONET website (https://aeronet.gsfc. nasa.gov/, last access: 12 December 2018). Daily AOD data with Level 2.0 quality were used in the analysis (Smirnov et al., 2000). Level 2.0 AOD retrievals are accurate up to 0.02 for mid-visible wavelengths.

MISR all data are available through the MISR website (https://www.misr.jpl.nasa.gov, last access: 18 December 2018).

\section{Statistics}

We have used two statistical parameters to compare data retrievals from space-borne and ground-based sensors, including the following.

1. Correlation coefficient $(R)$ : the correlation coefficient is a parameter to measure data dependence. If the value of $R$ is close to 0 , it indicates weak data agreement. And values close to 1 or -1 indicate that data retrievals are positively or negatively linearly related (Cheng et al., 2012).

2. Good fraction ( $G$ fraction): the $G$ fraction indicator uses a data confidence range defined by MISR and MODIS (Bruegge et al., 1998; Remer et al., 2005) over the land and ocean that combines the absolute and relative criterion and weights data equally such that small abnormalities will not affect the inter-comparison statistics (Kahn et al., 2009). In this study, we use the MODIS confidence range which defines data retrieval as "good" if the difference between MODIS and AERONET is less than

$\Delta \tau= \pm 0.03 \pm 0.05 \tau_{\mathrm{AER}}$ over ocean and

$\Delta \tau= \pm 0.05 \pm 0.15 \tau_{\mathrm{AER}}$ over land,

where $\tau_{\mathrm{AER}}$ is the optical depth retrieved using AERONET stations. The $G$ fraction is the percentage of MODIS data retrievals that satisfies Eqs. (1) and (2) over ocean and land respectively. Optical depth threshold over land (Eq. 1) is higher than over ocean (Eq. 2) due to harder data retrievals and high data instability over land.
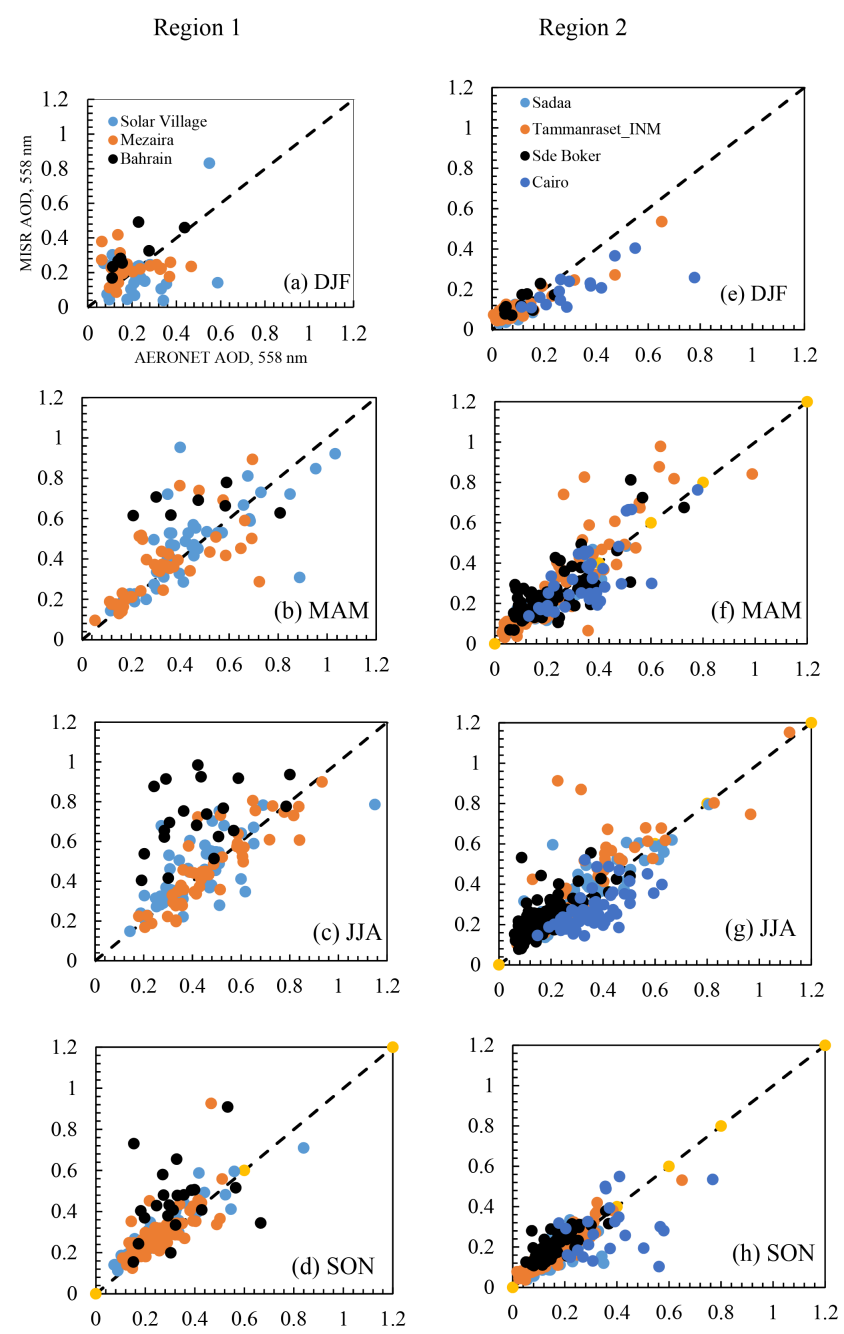

Figure 2. Scatter plot of MISR AOD versus AERONET AOD based on seasons and aerosols categorization.

An advantage of using a data confidence range is excluding small fraction data outliers from producing an inexplicably large influence on comparison statistics by weighting all events equally.

\section{Results and discussion}

\subsection{Validating MISR and MODIS AOD retrievals against AERONET observations over the Middle East and North Africa}

Illustrated in Figs. 2 and 3 and Tables 2 and 3 is a regression analysis of MISR and Terra MODIS AOD products against AERONET AOD over the seven AERONET sites, shown in Table 1, from 2000 to 2015.

The correlation coefficient between MISR and AERONET $\mathrm{AOD}$ at region 1 is equal to or above 0.85 except in Bahrain during DJF and JJA (Fig. 2 and Table 2), which could be 

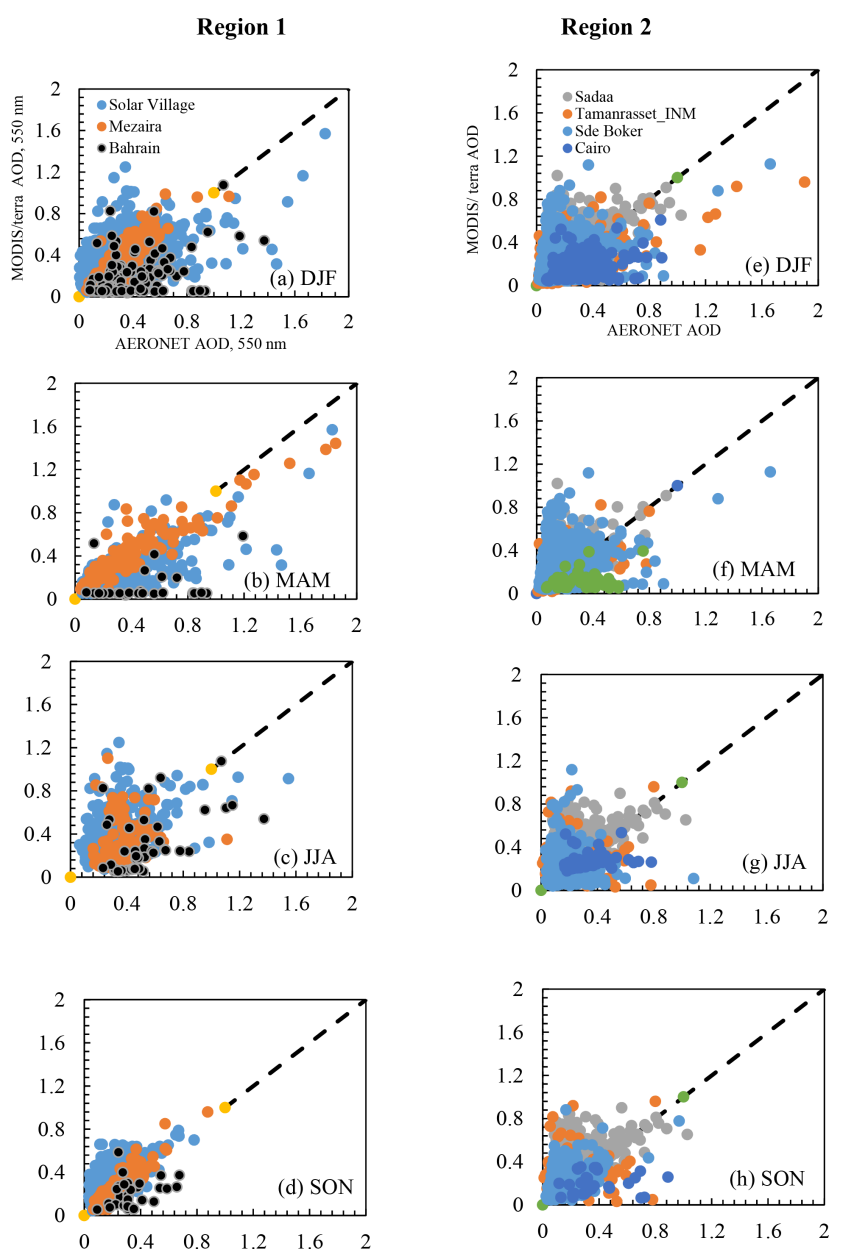

Figure 3. Scatter plot of MODIS AOD versus AERONET AOD based on seasons and aerosols categorization.

attributed to a lack of data and the impact of water surface reflectivity over Bahrain. Similar correlation coefficient values were found in region 2 where MISR-AERONET AOD shows smaller deviations from the MODIS data (Figs. 2 and 3 and Table 3). In general, the MODIS-AERONET AOD correlation coefficient is lower than those of MISR at all sites, except Mezaira, where the MISR and MODIS matched AERONET AOD correlation almost match. The lowest MODIS-AERONET AOD correlation coefficient was found over Cairo but could be attributed to the lack of data availability at this location (Fig. 3e-h). Low values of the MODIS-AERONET correlation coefficient are also found over Saada, Taman, and Sde Boker sites.

Over all AERONET stations, the number of MODIS AERONET matched AODs are 4 to 8 times those of MISR, which is expected from the MISR's sampling.

Comparisons show that the difference between MISR and MODIS retrievals at the selected AERONET sites could be significant as expected from the MODIS DT algorithm performance over bright land surfaces (Kokhanovsky et al., 2007).

High AOD values over regions 1 and 2 measured by both the AERONET and satellites' sensors indicate higher dust activities that peaks during May-August during dust storm season. Higher AOD values recorded during SON over the Cairo station could be caused by seasonal rice straw burning by farmers in Cairo, an environmental phenomena known as the Cairo "black cloud" (Marey et al., 2010). As shown in Fig. 3, the daily variability in MODIS measurements is larger than that of MISR in all the three regions. In general, MODIS tends to underestimate the AOD values on low-dust seasons (Figs. 2 and 3 and Tables 2 and 3).

The MODIS underestimated AOD values are more noticeable over Bahrain. This could be attributed to the large water body surrounding Bahrain, which should affect surface reflectivity. Moreover, water in the Arabian Gulf has been polluted in recent years (Afnan, 2015), leading to possible changes in water color and uncertainties in calculating surface reflectivity. The patchy land surface or pixel grid contaminated by the water body is the dominant error source for MODIS aerosol inversion over the land areas (He et al., 2010).

Compared to MODIS, MISR's outperformance in retrieving AOD over region 1 including vast highly reflective desert areas can be attributed to its multispectral and multiangular coverage, which make MISR provide better viewing over a variety of landscapes. Meanwhile, MISR retrieval also takes into consideration aerosols' particle nonsphericity, which could have a significant effect on its AOD retrievals (von Hoyningen-Huene and Posse, 1997). MISR's retrieval did not perform well over the Cairo site due to a lack of matched points in most of the seasons (15 in DJF, 39 in MAM, 61 in JJA, and 23 in SON during 2000-2015).

\subsection{Trends of AOD MISR, MODIS, and AERONET retrievals over the Middle East and North Africa}

Figure 4 shows time series of monthly mean AOD derived from MODIS/Aqua, MODIS/Terra, MISR, and AERONET over (a) dust-, (b) biomass-burning-, and (c) mixed-aerosoldominated aerosol regions. The satellite AOD trends are calculated from the data collocated with AERONET observations.

MODIS/Aqua and MISR AODs at Solar Village have positive trends, while MODIS/Terra AODs have negative trends along the time series shown in Fig. 4a. MODIS/Aqua AODs differ from those of MODIS/Terra. The discrepancy between Aqua and Terra retrievals could be related to instrument calibration or to the difference in aerosol and cloud conditions from the morning to the afternoon. Both Aqua and Terra MODIS underestimate AOD at Solar Village.

MISR AOD trend shows a better agreement with Solar Village AERONET AOD as compared to MODIS. 

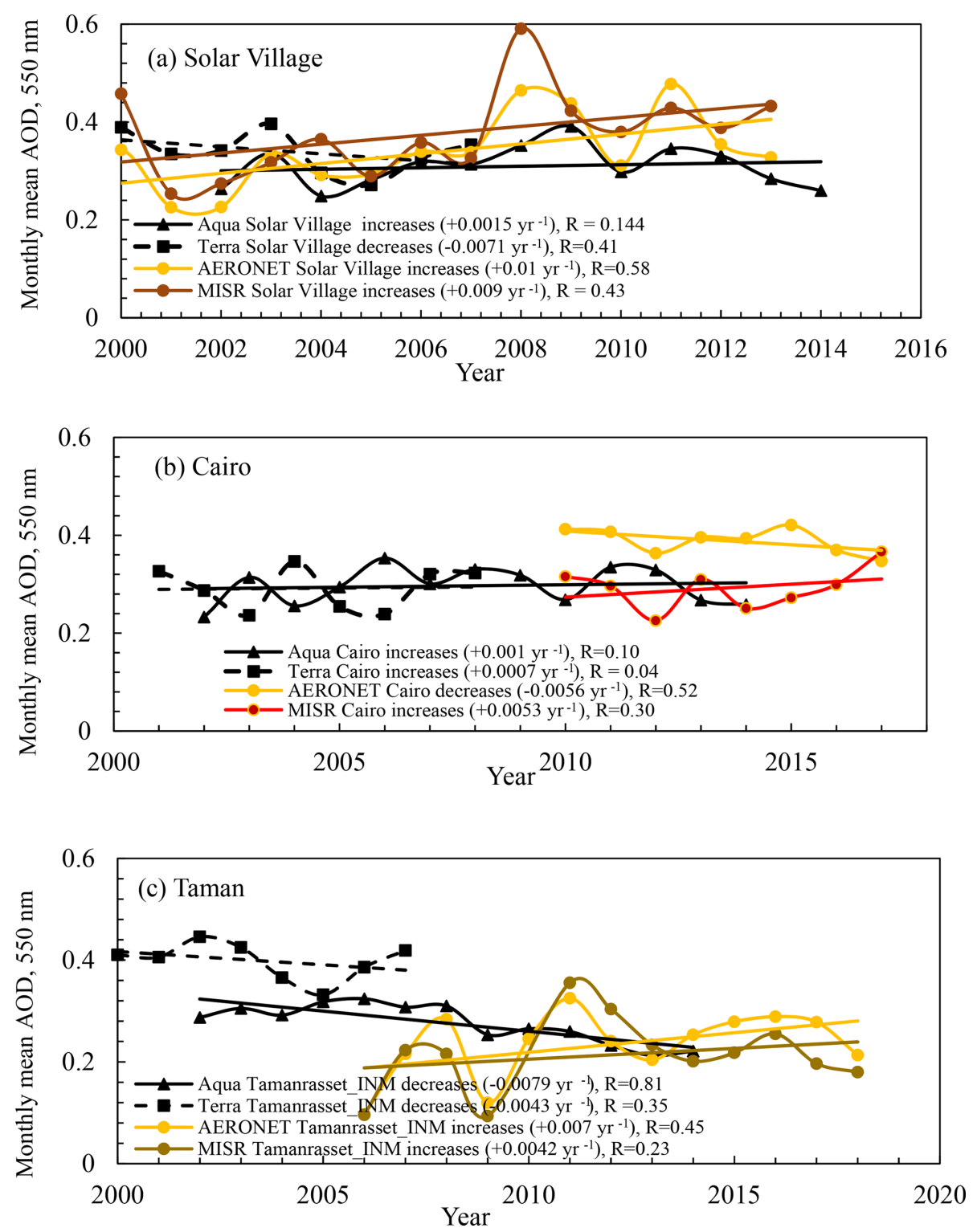

Figure 4. Time series of monthly mean AOD derived from MODIS/Aqua, MODIS/Terra, MISR, and AERONET over (a) dust-, (b) biomassburning, and (c) mixed-aerosol-dominated aerosol regions.

Both MODIS/Aqua and MODIS/Terra AODs show a stable trend over time at the Mezaira site (not shown in the figure) with a correlation coefficient of 0.11 and 0.04 respectively. MODIS/Aqua AODs over Bahrain (not shown in the figure) show less time trend stability compared to those at Solar Village with a correlation coefficient of 0.63 . MODIS/Aqua, MODIS/Terra, and MISR AOD depicts a positive trend over Cairo (Fig. 4b). In the Taman site (Fig. 4c), MODIS/Aqua, MODIS/Terra, and MISR AOD agree with Taman AERONET on a positive trend indicating data stability over this site.
The long-range (2000-2015) trend indicates that the contradictory AOD trend of Terra and Aqua is site-dependent and does not necessarily apply everywhere.

The AOD difference between Terra and Aqua could be used as another indicator of the long-term satellite performance. The AOD difference (Terra AOD minus Aqua AOD) varies from -0.01 to 0.19 and from -0.10 to 0.18 over Solar Village and Taman respectively (Fig. 5). Over the Solar Village, Terra overestimates AOD during 2002-2004 and underestimates the AOD after 2005. Taman shows a similar trend; however the over- and underestimation amount is not similar for all sites. This is an indication that Aqua and Terra retrieval disagreements take place regardless of the region but 
Table 2. Statistics for dust sites. $R$ : correlation coefficient; RMSD: root mean square deviation; $G$ fraction: good fraction; $N$ : number of observations

\begin{tabular}{|c|c|c|c|c|c|c|c|}
\hline \multirow{2}{*}{$\begin{array}{l}\text { AERONET } \\
\text { site }\end{array}$} & \multirow[t]{2}{*}{ Sensor } & \multirow[t]{2}{*}{ Season } & \multicolumn{2}{|c|}{ Mean value } & \multirow[t]{2}{*}{$N$} & \multirow[t]{2}{*}{$R$} & \multirow{2}{*}{$\begin{array}{r}G \text { fraction } \\
(\%)\end{array}$} \\
\hline & & & AERONET & Satellite & & & \\
\hline \multirow{8}{*}{ Solar Village } & \multirow{4}{*}{ MISR } & DJF & $0.18 \pm 0.15$ & $0.23 \pm 0.13$ & 24 & 0.94 & 79.1 \\
\hline & & MAM & $0.45 \pm 0.21$ & $0.47 \pm 0.20$ & 43 & 0.94 & 86.0 \\
\hline & & JJA & $0.39 \pm 0.16$ & $0.42 \pm 0.16$ & 57 & 0.90 & 82.4 \\
\hline & & SON & $0.25 \pm 0.14$ & $0.29 \pm 0.12$ & 50 & 0.99 & 82.0 \\
\hline & \multirow{4}{*}{$\begin{array}{l}\text { MODIS } \\
\text { Terra }\end{array}$} & $\mathrm{DJF}$ & $0.27 \pm 0.19$ & $0.33 \pm 0.17$ & 1500 & 0.48 & 51.80 \\
\hline & & MAM & $0.36 \pm 0.24$ & $0.26 \pm 0.17$ & 389 & 0.68 & 90.23 \\
\hline & & JJA & $0.34 \pm 0.17$ & $0.42 \pm 0.19$ & 429 & 0.41 & 54.31 \\
\hline & & SON & $0.22 \pm 0.10$ & $0.36 \pm 0.12$ & 471 & 0.51 & 28.87 \\
\hline \multirow{8}{*}{ Mezaira } & \multirow{4}{*}{ MISR } & DJF & $0.17 \pm 0.09$ & $0.23 \pm 0.07$ & 53 & 0.89 & 50.9 \\
\hline & & MAM & $0.34 \pm 0.18$ & $0.37 \pm 0.18$ & 41 & 0.90 & 78.0 \\
\hline & & JJA & $0.49 \pm 0.20$ & $0.47 \pm 0.21$ & 51 & 0.85 & 92.1 \\
\hline & & SON & $0.26 \pm 0.09$ & $0.30 \pm 0.12$ & 53 & 0.87 & 88.2 \\
\hline & \multirow{4}{*}{$\begin{array}{l}\text { MODIS } \\
\text { Terra }\end{array}$} & DJF & $0.32 \pm 0.15$ & $0.35 \pm 0.19$ & 198 & 0.86 & 74.74 \\
\hline & & MAM & $0.44 \pm 0.33$ & $0.45 \pm 0.27$ & 115 & 0.92 & 78.07 \\
\hline & & JJA & $0.39 \pm 0.14$ & $0.43 \pm 0.20$ & 89 & 0.81 & 71.91 \\
\hline & & SON & $0.28 \pm 0.13$ & $0.30 \pm 0.16$ & 97 & 0.87 & 77.31 \\
\hline \multirow{8}{*}{ Bahrain } & \multirow{4}{*}{ MISR } & DJF & $0.19 \pm 0.10$ & $0.30 \pm 0.10$ & 9 & 0.73 & 33.3 \\
\hline & & MAM & $0.47 \pm 0.20$ & $0.67 \pm 0.05$ & 7 & 0.89 & 28.5 \\
\hline & & JJA & $0.45 \pm 0.21$ & $0.74 \pm 0.21$ & 21 & 0.69 & 23.8 \\
\hline & & SON & $0.32 \pm 0.13$ & $0.45 \pm 0.16$ & 22 & 0.98 & 45.4 \\
\hline & \multirow{4}{*}{$\begin{array}{l}\text { MODIS } \\
\text { Terra }\end{array}$} & DJF & $0.42 \pm 0.29$ & $0.20 \pm 0.19$ & 121 & 0.41 & 93.38 \\
\hline & & MAM & $0.50 \pm 0.28$ & $0.13 \pm 0.15$ & 25 & 0.26 & 96.00 \\
\hline & & JJA & $0.55 \pm 0.26$ & $0.31 \pm 0.27$ & 42 & 0.50 & 88.09 \\
\hline & & SON & $0.35 \pm 0.14$ & $0.21 \pm 0.12$ & 29 & 0.32 & 93.10 \\
\hline
\end{tabular}

site sampling has significant effect on the amount of contradiction.

Statistical comparison between MISR and MODIS/Terra AOD at corresponding AERONET stations is performed by calculating $G$ fraction using $\Delta \tau= \pm 0.05 \pm 0.15 \tau_{\text {AERO }}$ as a confidence interval. Over region 1, MISR AOD retrievals are more accurate than MODIS retrievals. MODIS, however, performs better over region 2 sites with a high percentage of the data points falling within the confidence range (Tables 2 and 3). High light reflections from the desert landscape surrounding region 1 could have an effect on MODIS retrievals.

Excluding Bahrain and Cairo for low data retrievals the performance of MODIS tends to be similar over all regions with $\sim 64 \%$ of AOD retrievals falling within the $\Delta \tau=$ $\pm 0.05 \pm 0.15 \tau_{\text {AERO }}$ confidence range of the AERONET AOD, while MISR retrievals show better performance with $\sim 84 \%$ of the data falling within the same confidence range. This could be attributed to the low number of retrievals available for Bahrain and Cairo compared to other sites. The vast sea region surrounding Bahrain and the complex landscape in Cairo could also have an impact on retrievals.

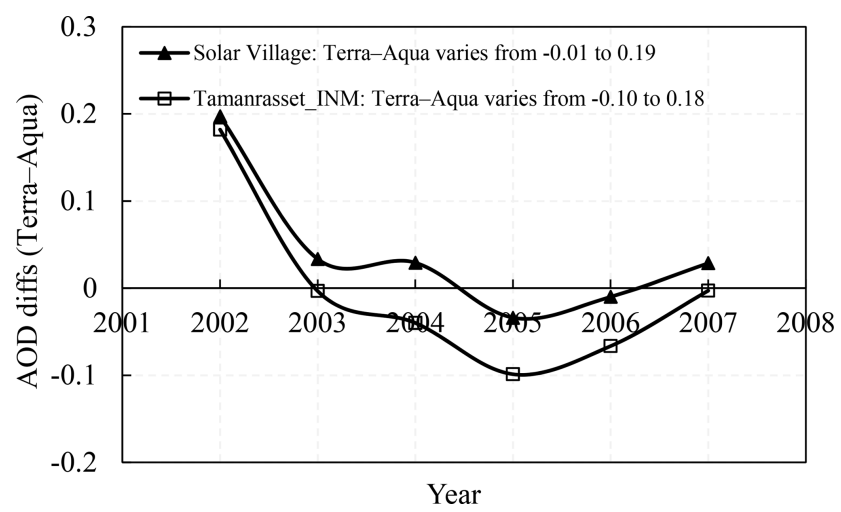

Figure 5. Long-term AOD difference for MODIS/Terra and MODIS/Aqua over the Solar Village and Taman sites.

\subsection{Evaluating the MISR and MODIS climatology over the Middle East and North Africa}

Comparisons between MISR and MODIS AOD at selected AERONET stations over the 2000-2015 period are shown in Figs. 6-12. 
Figure $6 \mathrm{a}$ and $\mathrm{b}$ show histograms of the MISR, MODIS, and AERONET AOD at Solar Village for MISR and MODIS data points collocated with AERONET observations. The mean, standard deviation, and number of measurements are also presented.

MISR tends to underestimate the frequency of low AOD compared to AERONET but overestimate the frequency of high AOD. MISR histograms show prominent peaks at 0.50 that can be also observed in AERONET and at 0.75 that could not be seen in AERONET. MISR and AERONET AOD climatology agree well with one another. MODIS also tends to underestimate the frequency of low-AOD events and overestimate the frequency of high-AOD events. High surface reflectance could cause overestimation in MODIS AOD (Ichoku et al., 2002). Both MISR and MODIS provide a good representation of the AOD climatology as compared to AERONET at Solar Village. The Mezaira station, which is located in an arid region in the United Arab Emirates (UAE), has a similar climatology to the Solar Village site with dust dominating aerosol. Figure $7 \mathrm{a}$ and $\mathrm{b}$ show histograms of the MISR, MODIS, and AERONET AOD at Mezaira.

Similar to the Solar Village, there is a big difference between the number of samples in the matched dataset and full AERONET climatology. For MISR there are 213 matched cases and for MODIS there are 498 compared to the 2245 for the entire site. This has an impact on the overall assessment showing significant differences between the matched data and the full climatology for both MISR and MODIS. First, for the MISR case, the matched AERONET data have the highest frequency at AOD of 0.15 and 0.35 , but the climatology shows the highest frequency at an AOD of 0.25. AODs in the range of 0.25 to 0.30 are undersampled relative to the climatology, and an AOD greater than 0.35 matches the climatology with less than $2 \%$ AOD greater than 0.85 . MODIS matched AERONET data show prominent peaks at 0.3 and 0.4 compared to the climatology that has a single peak at 0.30 .

For AOD values between 0.25 and 0.40 MODIS data were found to be undersampled, which is similar to MISR data between 0.65 and 0.70 and at 0.35 .

MISR AOD retrievals matched to AERONET capture the variability in the distribution, but as in the case of Solar Village the frequency of low-AOD events is underestimated but the frequency of high-AOD events matched AERONET data. MISR also captures events with AOD greater than 1. A similar situation is seen in the MODIS comparison, but MODIS appears to do a better job capturing the overall shape of the AERONET AOD histogram for this site.

The Bahrain AERONET site is located in Manama fairly close to the Arabian Gulf, a location very different from the previous two sites. The site is also located in an urban area and suffers from significant load of anthropogenic aerosols as a consequence of rapid aluminium industrial development (Farahat, 2016). Figure $8 \mathrm{a}$ and $\mathrm{b}$ show histograms of the MISR, MODIS, and Bahrain AERONET measurements with
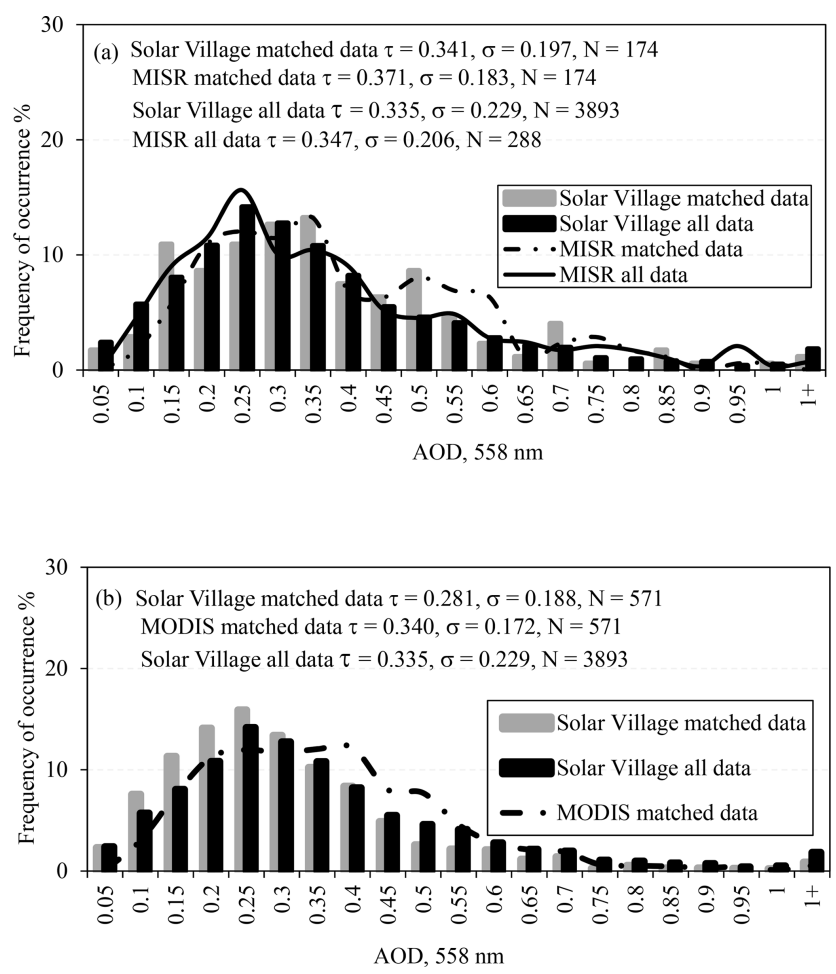

Figure 6. Histogram of the MISR, MODIS, and Solar Village AERONET measurements (a) MISR and (b) MODIS data retrievals.

statistical analysis displayed. The AERONET data matched to MISR show significant peaks at $0.20,0.30,0.45,0.55,0.7$, 0.8 , and 0.95 not seen in the all-data climatology that has peaks at 0.55 and 0.70 . AODs less than 0.15 are not representative in the matched dataset at all. MISR is representing the peaks at 0.45 in the matched dataset but misses the peaks at $0.20,0.30$, and 0.35 . The MISR climatology agrees well with the AERONET all-data climatology for all AOD. MODIS on the other hand shows an extremely large frequency of AOD at 0.1 not represented by AERONET coupled with an underestimation of AOD greater than 0.3. This could be attributed to the size of the matching window and MODIS retrievals preferentially coming from the Arabian Gulf.

The Saada station is located close to some hiking trails at the Agoundis Valley in the Atlas Mountains about $197 \mathrm{~km}$ from the city of Marrakesh.

MISR AODs matched to AERONET agree well with MISR full climatology retrievals over the Saada station. Both retrievals slightly underestimate Saada full climatology and overestimate Saada matched data retrievals at AOD equal to 0.2 while showing good agreement for AOD greater than 0.2. MODIS matched to AERONET retrievals overestimate the frequency of AOD greater than 0.3. While MODIS AOD matched to AERONET captures climatology at AOD between 0.2 and 0.25 , AOD frequency retrievals are undersampled at AOD between 0.1 and 0.15 , with about $13 \%$ 
Table 3. Statistics for biomass and mixed sites, parameters as in Table 2.

\begin{tabular}{|c|c|c|c|c|c|c|c|}
\hline \multirow{2}{*}{$\begin{array}{l}\text { AERONET } \\
\text { site }\end{array}$} & \multirow[t]{2}{*}{ Method } & \multirow[t]{2}{*}{ Season } & \multicolumn{2}{|c|}{ Mean value } & \multirow[t]{2}{*}{$N$} & \multirow[t]{2}{*}{$R$} & \multirow{2}{*}{$\begin{array}{r}G \text { fraction } \\
(\%)\end{array}$} \\
\hline & & & AERONET & Satellite & & & \\
\hline \multirow{8}{*}{ Saada } & \multirow{4}{*}{ MISR } & DJF & $0.07 \pm 0.02$ & $0.07 \pm 0.02$ & 43 & 0.93 & 100.0 \\
\hline & & MAM & $0.17 \pm 0.10$ & $0.17 \pm 0.09$ & 47 & 0.89 & 93.6 \\
\hline & & JJA & $0.30 \pm 0.14$ & $0.31 \pm 0.14$ & 53 & 0.93 & 93.1 \\
\hline & & SON & $0.14 \pm 0.07$ & $0.13 \pm 0.06$ & 51 & 0.94 & 96.0 \\
\hline & \multirow{4}{*}{$\begin{array}{l}\text { MODIS } \\
\text { Terra }\end{array}$} & DJF & $0.23 \pm 0.16$ & $0.32 \pm 0.21$ & 550 & 0.57 & 57.8 \\
\hline & & MAM & $0.24 \pm 0.18$ & $0.39 \pm 0.23$ & 90 & 0.43 & 44.4 \\
\hline & & JJA & $0.30 \pm 0.17$ & $0.45 \pm 0.18$ & 201 & 0.40 & 45.2 \\
\hline & & SON & $0.19 \pm 0.13$ & $0.22 \pm 0.14$ & 162 & 0.71 & 72.3 \\
\hline \multirow{8}{*}{ Taman } & \multirow{4}{*}{ MISR } & DJF & $0.07 \pm 0.10$ & $0.09 \pm 0.06$ & 69 & 0.92 & 85.5 \\
\hline & & MAM & $0.22 \pm 0.18$ & $0.25 \pm 0.22$ & 86 & 0.97 & 81.3 \\
\hline & & JJA & $0.42 \pm 0.31$ & $0.45 \pm 0.28$ & 57 & 0.85 & 78.9 \\
\hline & & SON & $0.14 \pm 0.11$ & $0.15 \pm 0.10$ & 72 & 0.94 & 95.8 \\
\hline & \multirow{4}{*}{$\begin{array}{l}\text { MODIS } \\
\text { Terra }\end{array}$} & DJF & $0.19 \pm 0.22$ & $0.18 \pm 0.16$ & 319 & 0.67 & 81.8 \\
\hline & & MAM & $0.24 \pm 0.19$ & $0.22 \pm 0.17$ & 67 & 0.55 & 83.5 \\
\hline & & JJA & $0.37 \pm 0.32$ & $0.29 \pm 0.20$ & 69 & 0.69 & 84.0 \\
\hline & & SON & $0.14 \pm 0.14$ & $0.13 \pm 0.10$ & 117 & 0.54 & 84.6 \\
\hline \multirow{8}{*}{ Cairo } & \multirow{4}{*}{ MISR } & DJF & $0.33 \pm 0.17$ & $0.17 \pm 0.09$ & 15 & 0.94 & 100.0 \\
\hline & & MAM & $0.35 \pm 0.13$ & $0.33 \pm 0.15$ & 39 & 0.99 & 82.0 \\
\hline & & JJA & $0.35 \pm 0.09$ & $0.27 \pm 0.08$ & 61 & 0.99 & 967 \\
\hline & & SON & $0.37 \pm 0.14$ & $0.28 \pm 0.13$ & 23 & 0.97 & 78.2 \\
\hline & \multirow{4}{*}{$\begin{array}{l}\text { MODIS } \\
\text { Terra }\end{array}$} & DJF & $0.33 \pm 0.16$ & $0.20 \pm 0.11$ & 158 & 0.30 & 95.5 \\
\hline & & MAM & $0.32 \pm 0.16$ & $0.12 \pm 0.08$ & 39 & 0.25 & 100.0 \\
\hline & & JJA & $0.35 \pm 0.14$ & $0.28 \pm 0.07$ & 58 & 0.17 & 94.8 \\
\hline & & SON & $0.38 \pm 0.19$ & $0.20 \pm 0.09$ & 29 & 0.07 & 93.8 \\
\hline \multirow{8}{*}{ Sde Boker } & \multirow{4}{*}{ MISR } & DJF & $0.11 \pm 0.06$ & $0.13 \pm 0.05$ & 10 & 0.87 & 90.0 \\
\hline & & MAM & $0.21 \pm 0.13$ & $0.24 \pm 0.13$ & 76 & 0.68 & 75.0 \\
\hline & & JJA & $0.16 \pm 0.08$ & $0.21 \pm 0.08$ & 142 & 0.85 & 66.9 \\
\hline & & SON & $0.162 \pm 0.07$ & $0.20 \pm 0.06$ & 54 & 0.89 & 79.6 \\
\hline & \multirow{4}{*}{$\begin{array}{l}\text { MODIS } \\
\text { Terra }\end{array}$} & DJF & $0.16 \pm 0.12$ & $0.23 \pm 0.14$ & 1312 & 0.36 & 53.5 \\
\hline & & MAM & $0.21 \pm 0.18$ & $0.24 \pm 0.19$ & 338 & 0.34 & 65.6 \\
\hline & & JJA & $0.16 \pm 0.09$ & $0.33 \pm 0.13$ & 392 & 0.27 & 17.3 \\
\hline & & SON & $0.16 \pm 0.09$ & $0.23 \pm 0.12$ & 477 & 0.46 & 58.4 \\
\hline
\end{tabular}

fewer events than Saada all-data retrievals at AOD equal to 0.1 .

Figure $9 \mathrm{a}$ and $\mathrm{b}$ indicate a right-skewed distribution of Saada AOD towards small AOD values with $10.3 \%$ and $30.1 \%$ of AOD $>0.4$ as measured by MISR and MODIS respectively. Taking into consideration MODIS overestimation we conclude that the Saada site is characterized by small AOD values and this could be related to the land topology where the station is located.

While MISR captures high-AOD climatology over Saada, both MISR and MODIS underestimate the frequency of lower AOD events. Nevertheless, MISR captures the climatology of AOD less than 0.1 missed by MODIS retrievals.
The Taman AERONET station is located at the oasis city of Tamanrasset, which lies in Ahaggar National Park in southern Algeria.

Figure 10a and $\mathrm{b}$ depict that Taman AERONET AOD climatology is similar to those at Saada and has a high frequency of low-AOD events. Both MISR AOD matched to AERONET and MISR all data do not capture the frequency of AOD less than 0.1 or larger than 1 well, while they describe the climatology for AOD in the range of 0.1 to 1 well. MODIS AOD matched data to AERONET correctly describe climatology with a slight overestimation of AOD frequencies between 0.05 and 0.15 while not capturing AOD frequencies greater than 1. MISR and MODIS show similar prominent peaks at 0.1 and 0.25 not observed in Taman AERONET AOD climatology, with more peaks observed by MISR at 0.5 , 

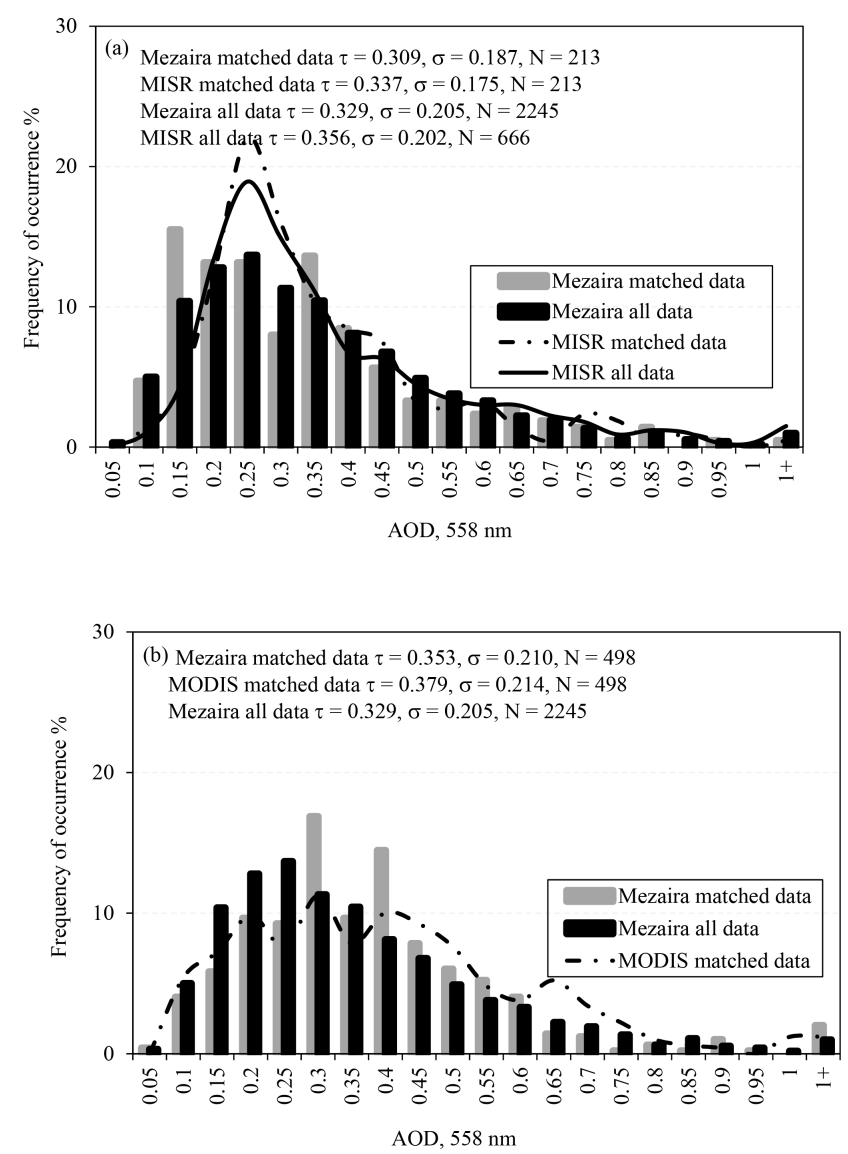

Figure 7. Histogram of the MISR, MODIS, and Mezaira AERONET measurements (a) MISR and (b) MODIS data retrievals.

0.75 , and 0.85. Average AOD in Saada and Taman is $\sim 50 \%$ less than observed at Solar Village, Mezaira, and Bahrain sites.

Except for AOD greater than 1 where ground observations could be more robust, both MISR and MODIS retrievals can provide very good climatology matching over the Taman site.

Taking into consideration the lower number of MISR matching AERONET observations compared to MODIS $21.3 \%$ and $49.6 \%$ over Saada and Taman respectively, MISR outperforms over these two sites, which can be attributed to its multi-angle viewing capabilities over complex terrains including mountainous areas (Atlas Mountains).

Cairo is a mega city well known for its high pollution due to traffic and agriculture activities.

MISR and MODIS matched data correctly capture AOD climatology over Cairo compared to AERONET as shown in Fig. 11a and b. MISR retrievals collocated with AERONET overestimate prominent peaks of AERONET AOD at 0.150.35 , while they underestimate AERONET AOD greater than 0.35. MISR all-data AOD climatology over the Cairo station agrees better with the AERONET AOD climatology vs. collocated dataset with some oversampling at 0.25 .
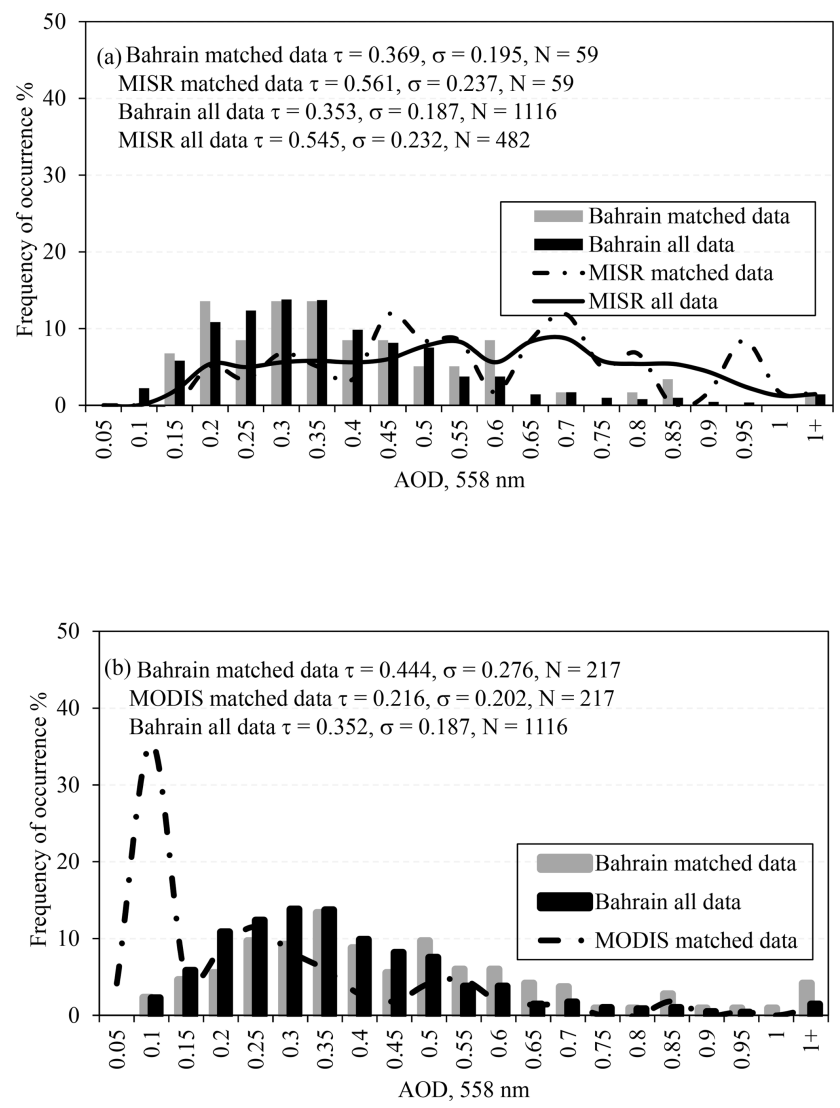

Figure 8. Histogram of the MISR, MODIS, and Bahrain AERONET measurements (a) MISR and (b) MODIS data retrievals.

The frequency of high-AOD retrievals greater than 0.8 has not been captured by MISR matched or all-data retrievals. MODIS matched to AERONET AOD is also able to well represent Cairo climatology data with a high overestimation of AOD frequency between 0.05 and 0.2 and an underestimation of AOD larger than 0.4.

The complex landscape and local emissions in Cairo could impose major challenges in MODIS AOD retrievals. Moreover, Cairo is one of the most densely populated cities in the world that hosts major commercial and industrial centers in North Africa. Cairo also has a complicated aerosol structure developed by long-range-transported dust in the spring, biomass burning in the fall, strong traffic, and industrial emissions (Marey et al., 2010).

Over the Cairo station, MODIS correctly represents ground observations for AOD between 0.2 and 0.4 while MISR all data better represent AOD climatology for AOD greater than 0.4 .

MISR and MODIS climatology at Sde Boker is illustrated in Fig. 12a and $b$.

MISR "matched" AOD frequency shows significant underestimation for AOD less than 0.2 and an overestimation between 0.2 and 0.4 compared with AERONET retrievals. 

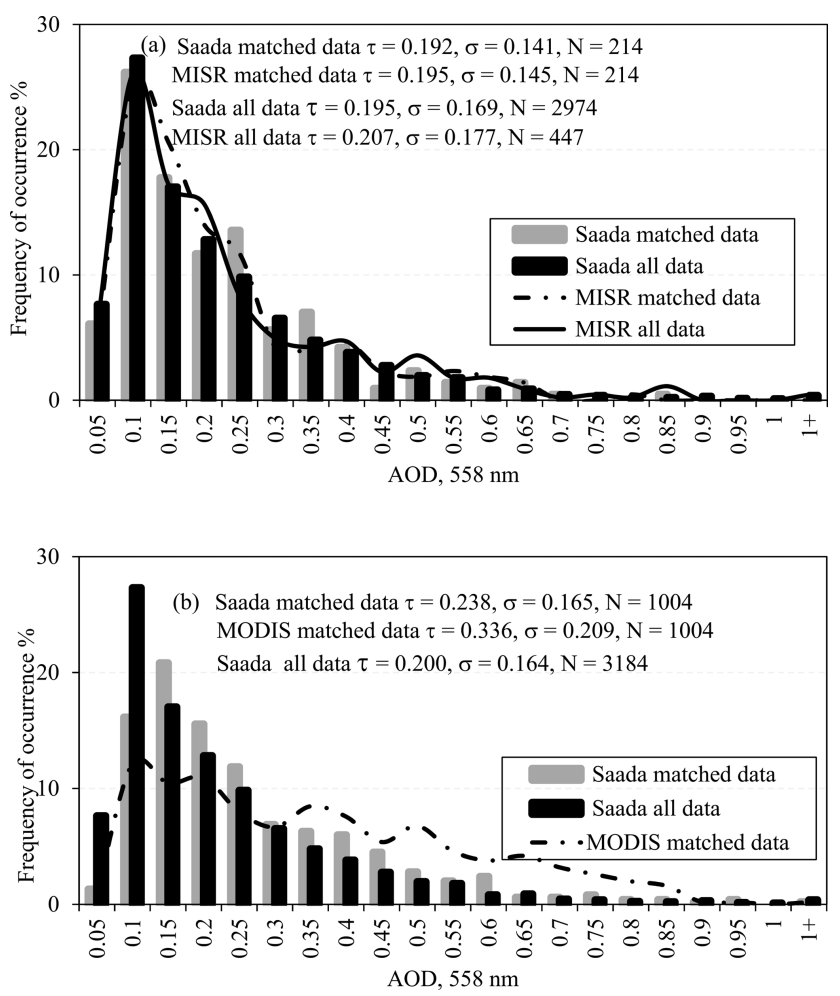

Figure 9. Histogram of the MISR, MODIS, and Saada AERONET measurements (a) MISR and (b) MODIS data retrievals.

MISR correctly captures the climatology for AOD events greater than 0.4. MISR matched and all-data retrieval peaks at 0.2 , producing a high frequency of AOD oversampling compared to AERONET. MISR data retrievals do not capture the climatology for AOD less than 0.1 over this site coincident with what was previously observed over other sites. MODIS matched AERONET data underestimate the frequency of AOD less than 0.2, while they overestimate the frequencies between 0.2 and 0.6 and match the frequencies of higher AOD events larger than 0.6 well. MODIS retrievals are characterized by two prominent peaks at 0.1 and 0.25 that are not found in the AERONET matched data.

At Sde, MISR and MODIS retrievals are better at matching the frequency of high-AOD retrievals (greater than 0.4) than the frequency of low-AOD retrievals. This could be an effect of possible long-range transport to the Sde Boker site (Farahat et al., 2016b) along with complex mixtures of dust, pollution, smoke, and sea salt that could result in uncertainties in MISR and MODIS aerosol model selection.

In the summary, MISR tends to overestimate AOD $>0.4$ over Solar Village and Bahrain and underestimate AOD $>0.4$ over Cairo. MISR retrievals also match AOD $>0.4$ for Mezaira and Sde Boker, while they agree with AERONET over Saada and Taman at all ranges of AOD. This could be expounded by insufficient particle absorption in the MISR algorithm (Kahn et al., 2005).
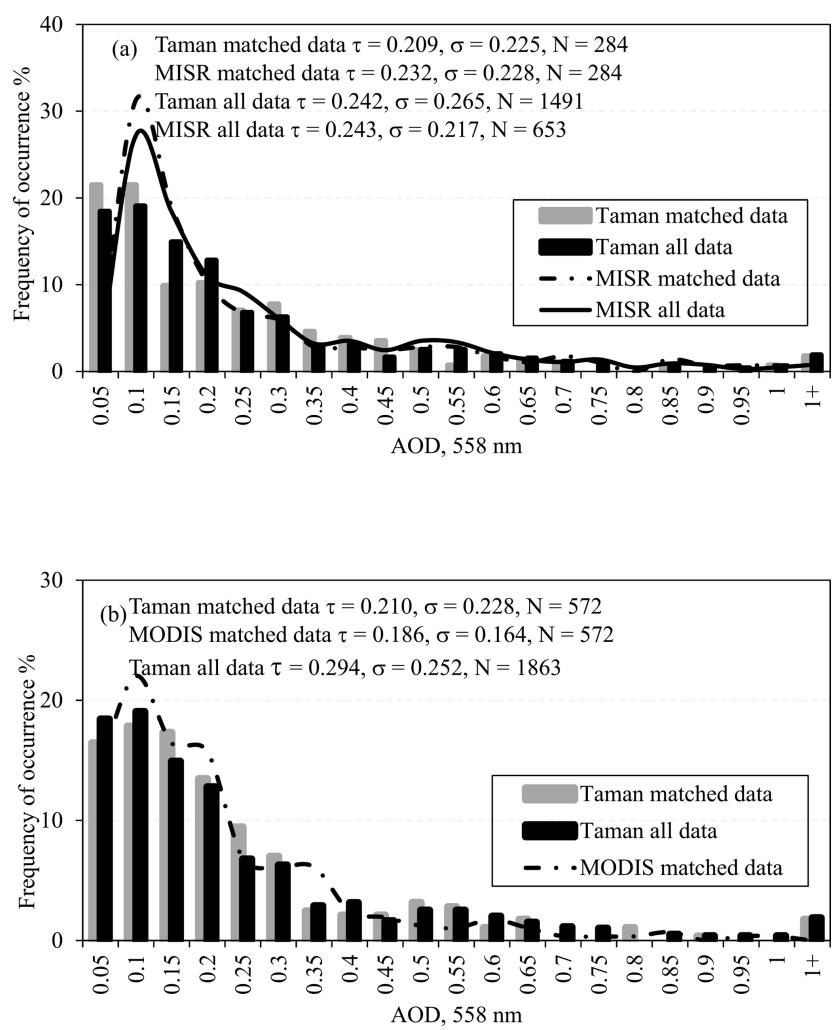

Figure 10. Histogram of the MISR, MODIS, and Taman AERONET measurements (a) MISR and (b) MODIS data retrievals.

Spherical particle absorption is produced by externally mixing small black carbon particles.

The percentage of MISR, MODIS, and AERONET AOD greater than 0.4 recorded is shown in Table 4. Over Solar Village, both MISR and MODIS capture high AOD greater than 0.4 well, with very good agreement with the ground observations. Over Mezaira, both MISR and MODIS are overestimating the percentage of AOD greater than 0.4 by about $17.7 \%$ and $12.7 \%$ respectively. MISR all data agree well with AERONET all data in representing high AOD over Bahrain while MODIS shows significant underrepresentation of those events by about $13 \%$, which is less than that reported by the Bahrain AERONET station. At Saada, MISR AOD agrees with AERONET in showing a low percentage of AOD greater than 0.4, while MODIS retrievals overestimate the percentage by about $24 \%$. MISR AOD over the Taman AERONET station shows very good agreement, while MODIS is slightly underestimating AOD. Among all seven sites considered in this study, Sde Boker shows lowest occurrence of AOD greater than 0.4, which is confirmed by both MISR and MODIS retrievals. Cairo AERONET records the highest frequency of AOD $>0.4$; however this is largely underestimated by both MISR and MODIS retrievals. 
Table 4. MISR coverage for 6 days of major dust activity over the Arabian Peninsula during March 2009.

\begin{tabular}{|c|c|c|c|c|c|c|}
\hline & \multicolumn{2}{|c|}{ AERONET } & \multicolumn{2}{|c|}{ MISR } & \multicolumn{2}{|c|}{ MODIS } \\
\hline & $N$ & $\begin{array}{r}\text { AOD } \\
\%>0.4\end{array}$ & $N$ & $\begin{array}{r}\text { AOD } \\
\%>0.4\end{array}$ & $N$ & $\begin{array}{r}\text { AOD } \\
\%>0.4\end{array}$ \\
\hline Solar Village & 3893 & 27.17 & 684 & 32.8 & 2789 & 30.1 \\
\hline Mezaira & 2245 & 28.01 & 547 & 45.7 & 498 & 40.7 \\
\hline Bahrain & 1116 & 31.36 & 676 & 35.8 & 217 & 18.4 \\
\hline Saada & 2974 & 10.32 & 667 & 11.5 & 1004 & 34.6 \\
\hline Taman & 798 & 15.78 & 845 & 22.6 & 572 & 9.4 \\
\hline Cairo & 2222 & 38.79 & 620 & 17.7 & 284 & 4.2 \\
\hline Sde & 5722 & 4.28 & 675 & 9.0 & 2519 & 12.8 \\
\hline
\end{tabular}

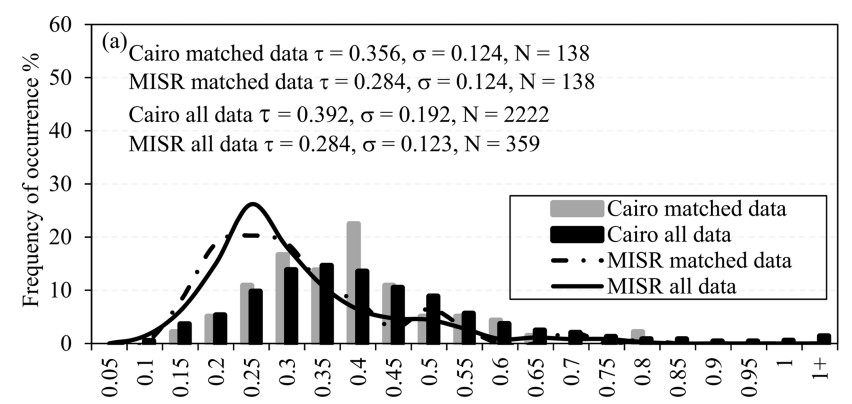

AOD, $558 \mathrm{~nm}$

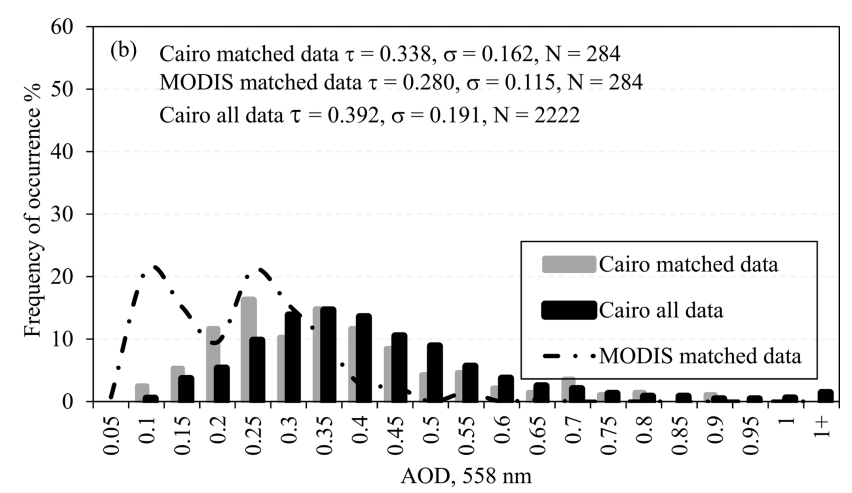

Figure 11. Histogram of the MISR, MODIS, and Sde Boker AERONET measurements (a) MISR and (b) MODIS data retrievals.

It can be concluded from the previous discussion that the atmosphere around Saada, Taman, and Sde Boker sites is relatively clean and aerosol loads are small compared to Solar Village, Mezaira, Bahrain, and Cairo. However this could be affected by the location where the AERONET station is installed; for example, the Saada and Taman stations are installed in a remote mountainous region away from urbanization, while the Cairo station is installed in the middle of a large residential region with significant local emissions.
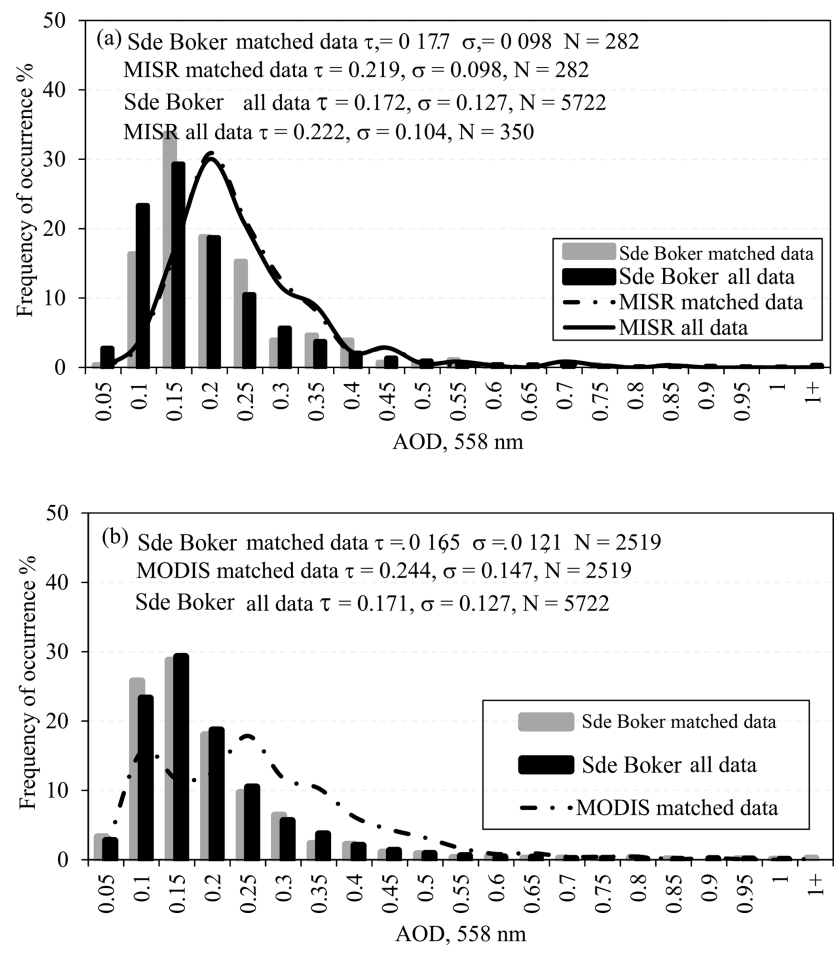

Figure 12. Histogram of the MISR, MODIS, and Cairo AERONET measurements (a) MISR and (b) MODIS data retrievals.

\section{Conclusion}

The performance of MODIS and MISR retrievals with corresponding AERONET measurements over different geographic locations in the Middle East and North Africa was investigated during 2000-2015.

Long-term observations show dissimilar AOD trends between MODIS/Aqua, MODIS/Terra, MISR, and AERONET measurements. MODIS/Aqua matched AERONET retrievals show a stable trend over all sites while MODIS/Terra matched AERONET retrievals show a significant downward trend indicating possible changes in the sensor performance. 
MISR matched AERONET AOD data depict a high correlation compared to AERONET, indicating good agreement with ground observations, with about $84 \%$ of AOD retrievals falling within the expected confidence range.

The consistency of MODIS and AERONET AOD varies based on the season, study area, and dominant aerosols type, with about $64 \%$ of the retrieved AOD values falling within the expected confidence range with the lowest performance over mixed particle regions.

Comparing satellites' AOD retrievals with corresponding AERONET measurements shows that space-borne data retrieval accuracy can be affected by the landscape, topology, and AOD range at which data are retrieved.

Few AERONET sites are verified sites where MISR and MODIS retrievals agree well with ground observations, while in other sites only MISR or MODIS could correctly describe the climatology.

The AOD range at which MISR or MODIS could correctly describe ground observation is also investigated over different AERONET sites. Over Solar Village both MISR and MODIS tend to underestimate the frequency of low AOD and overestimate the frequency of high AOD compared to AERONET with MISR histograms showing prominent peaks at 0.50 , which matched AERONET data, and at 0.75, which could not be recorded in AERONET. MISR can capture the frequency of AOD greater than 1, which is mostly missed by MODIS. Both MISR and MODIS are found to provide a good representation of the AOD climatology over the Solar Village site.

Similar to Solar Village, MISR underestimates the frequency of lower AOD and overestimate frequencies of high AOD over Mezaira. MISR is able to correctly capture the frequency of AOD greater than 1, while MODIS retrievals are found to better represent the overall climatology. This is due to the low number of MISR matched AERONET retrievals compared to MODIS over this site. Prominent peaks at 0.3 and 0.4 were observed in MODIS matched Mezaira retrievals compared to the climatology, which has a single peak at 0.30 .

The large water body surrounding Bahrain makes MODIS data preferentially originate from the Arabian Gulf, which produces an extremely large frequency of AOD at 0.1 not observed in AERONET measurements paired with an underestimation of AOD greater than 0.3. Meanwhile, MISR retrievals agree well with AOD climatology over Bahrain.

MISR AOD retrievals slightly underestimate Saada climatology, while they show good agreement for AOD greater than 0.1. MODIS retrievals underestimate the frequency of AOD retrievals between 0.1 and 0.15 , match climatology at AOD between 0.2 and 0.25 , and overestimate the frequency of AOD greater than 0.3. The Saada site is characterized by a small frequency of low AOD values and this could be related to the landscape nature surrounding the Saada station. MISR is found to be outperforming over Saada and Taman stations, which can be attributed to its viewing multispectral and multiangular capabilities over mountainous regions.
MISR retrievals capture prominent peaks of AERONET data at 0.15 to 0.35 well, with a small underestimation observed at AOD greater than 0.3 over Cairo. Using either MISR matched data or MISR all data over Cairo was found to perform well in describing the climatology over this station. MODIS data retrievals are also able to well represent Cairo climatology with a high overestimation of AOD frequency between 0.05 and 0.2 and an underestimation of AOD larger than 0.4. While both MISR and MODIS describe climatology over the Cairo station well, MODIS can correctly represent ground observations between 0.2 and 0.4 .

Over Sde Boker both MISR and MODIS retrievals describe the climatology well; however they are more successful in matching the frequency of high AOD greater than 0.4.

Based on analyzing frequency of AOD greater than 0.4, it was found that Saada, Taman, and Sde Boker have better air quality compared to other sites, while Cairo was found to be the most polluted site.

The results presented in this study are important in providing a guideline for satellite retrievals end users on which sensor could provide reliable data over a certain geographic location and AOD range.

An adjacent geographic location and local climate among sites does not always guarantee that same sensor will provide consistent retrievals over all sites. For example, the Solar Village and Bahrain AERONET sites are surrounded by large desert regions and share almost similar climatic conditions, but MODIS is found to be more successful in describing climatology over Solar Village than over Bahrain, which could be attributed to different factors related to surface reflection, cloud coverage, and the large water body surrounding Bahrain. Thus, in order to decrease data uncertainty, it is important to determine which sensor provides the best retrieval over a certain geographic location and AOD range.

Data availability. MODIS data are available through https:// giovanni.gsfc.nasa.gov/giovanni, MISR data are available through https://www.misr.jpl.nasa.gov, and AERONET data are available through https://aeronet.gsfc.nasa.gov. All data can also be requested by contacting the corresponding author.

Competing interests. The author declares that he has no conflict of interest.

Acknowledgements. The author would like to acknowledge the support provided by the Deanship of Scientific Research (DSR) at the King Fahd University of Petroleum and Minerals (KFUPM) for funding this work through project no. IN161053. Portions of this work were performed at the Jet Propulsion Laboratory (JPL), California Institute of Technology, under a contract with the National Aeronautics and Space Administration. The author would like to thank Michael Garay (MJG) and Olga Kalashnikova (OVK) (JPL) for their suggestion of investigating satellite and 
AERONET matched data climatology and for their discussion during the data analysis. The author would also like to thank Hesham El-Askary (Chapman University) for recommending AERONET data over North Africa and the Middle East as well as for reviewing the English on an earlier version of the manuscript. We thank the MISR project for providing facilities and supporting contributions of MJG and OVK. Finally, we thank the reviewers for their suggestions, which improved the manuscript.

Edited by: Marc Salzmann

Reviewed by: two anonymous referees

\section{References}

Abdi, V., Flamant, C., Cuesta, J., Oolman, L., Flamant, P., and Khalesifard, H. R.: Dust transport over Iraq and northwest Iran associated with winter Shamal: A case study, J. Geophys. Res., 117, D03201, https://doi.org/10.1029/2011JD016339, 2012.

Ackerman, S., Strabala, K. I., Menzel, W. P., Frey, R. A., Moeller, C. C., and Gumley, L. E.: Discriminating clear sky from clouds with MODIS, J. Geophys. Res., 103, 141-157, https://doi.org/10.1029/1998JD200032, 1998.

Afnan, F.: Heavy metal, trace element and petroleum hydrocarbon pollution in the Arabian Gulf: Review, J. Assoc. Arab Univers. Basic Appl. Sci., 17, 90-100, https://doi.org/10.1016/j.jaubas.2014.02.001, 2015.

Ansmann, A., Petzold, A., Kandler, K., Tegen, I., Wendisch, M., Müller, D., Weinzierl, B., Müller, T., and Heintzenberg, J.: Saharan Mineral Dust Experiments SAMUM-1 and SAMUM-2: what have we learned?, Tellus B, 63, 403-429, https://doi.org/10.1111/j.1600-0889.2011.00555.x, 2011.

Basart, S., Pérez, C., Cuevas, E., Baldasano, J. M., and Gobbi, G. P.: Aerosol characterization in Northern Africa, Northeastern Atlantic, Mediterranean Basin and Middle East from direct-sun AERONET observations, Atmos. Chem. Phys., 9, 8265-8282, https://doi.org/10.5194/acp-9-8265-2009, 2009.

Böer, B.: An introduction to the climate of the United Arab Emirates (review), J. Arid Environ., 35, 3-16, https://doi.org/10.1006/jare.1996.0162, 1997.

Bou Karam, D., Flamant, C., Cuesta, J., Pelon, J., and Williams, E.: Dust emission and transport associated with a Saharan depression: February 2007 case, J. Geophys. Res., 115, D00H27, https://doi.org/10.1029/2009JD012390, 2010.

Bruegge, C., Chrien, N., Kahn, R., Martonchik, J., and Diner, D.: MISR radiometric uncertainty analyses and their utilization within geophysical retrievals, IEEE T. Geosci. Remote, 36, 1186-1198, https://doi.org/10.1088/0026-1394/35/4/61, 1998.

Cheng, M., You, C., Cao, J., and Jin, Z.: Spatial and seasonal variability of water-soluble ions in $\mathrm{PM}_{2.5}$ aerosols in 14 major cities in China, Atmos. Environ., 60, 182-192, https://doi.org/10.1016/j.atmosenv.2012.06.037, 2012.

Chin, M., Diehl, T., Tan, Q., Prospero, J. M., Kahn, R. A., Remer, L. A., Yu, H., Sayer, A. M., Bian, H., Geogdzhayev, I. V., Holben, B. N., Howell, S. G., Huebert, B. J., Hsu, N. C., Kim, D., Kucsera, T. L., Levy, R. C., Mishchenko, M. I., Pan, X., Quinn, P. K., Schuster, G. L., Streets, D. G., Strode, S. A., Torres, O., and Zhao, X.-P.: Multi-decadal aerosol variations from 1980 to 2009: a perspective from observations and a global model, At- mos. Chem. Phys., 14, 3657-3690, https://doi.org/10.5194/acp14-3657-2014, 2014.

Chu, D. A., Kaufman, Y. J., Remer, L. A., and Holben, B. N.: Remote sensing of smoke from MODIS airborne simulator during the SCAR-B experiment, J. Geophys. Res., 103, 979-987, https://doi.org/10.1029/98JD01148, 1998.

Derimian, Y., Karnieli, A., Kaufman, Y. J., Andreae, M. O., Andreae, T. W., Dubovik, O., Maenhaut, W., Koren, I., and Holben, B. N.: Dust and pollution aerosols over the Negev desert, Israel: Properties, transport, and radiative effect, J. Geophys. Res., 111, D05205, https://doi.org/10.1029/2005JD006549, 2006.

Dubovik, O. and King, M. D.: A flexible inversion algorithm for retrieval of aerosol optical properties from Sun and sky radiance measurements, J. Geophys. Res., 105, 20673-20696, https://doi.org/10.1029/2000JD900282, 2000.

Dubovik, O., Holben, B. N., Eck, T. F., Smirnov, A., Kaufman, Y. J., King, M. D., Tanre, D., and Slutsker, I.: Variability of absorption and optical properties of key aerosol types observed in worldwide locations, J. Atmos. Sci., 59, 590-608, https://doi.org/10.1175/15200469(2002)059<0590:VOAAOP>2.0.CO;2, 2002.

Dubovik, O., Sinyuk, A., Lapyonok, T., Holben, B., Mischenko, M., Yang, P., Eck, T., Volten, H., Muñoz, O., Veihelmann, B., van der Zande, W. J., Leon, J.-F., Sorokin, M., and Slutsker, I.: application of spheroid models to account for aerosol particle nonsphericity in remote sensing of desert dust, J. Geophys. Res., 111, D11208, https://doi.org/10.1029/2005JD006619, 2006.

Eck, T., Holben, B., Sinyuk, A., Pinker, R., Goloub, P., Chen, H., Chatenet, B., Li, Z., Singh, R., Tripathi, S., Reid, J., Giles, D., Dubovik, O., O’Neill, N., Smirnov, A., Wang, P., and Xia, X.: Climatological aspects of the optical properties of fine/coarse mode aerosol mixtures, J. Geophys. Res., 115, D19205, https://doi.org/10.1029/2010JD014002, 2010.

Elagib, N. and Addin Abdu, A.: Climate variability and aridity in Bahrain, J. Arid Environ., 36, 405-419, https://doi.org/10.1006/jare.1996.0237, 1997.

El-Askary, H., Farouk, R., Ichoku, C., and Kafatos, M.: Transport of dust and anthropogenic aerosols across Alexandria, Egypt, Ann. Geophys., 27, 2869-2879, https://doi.org/10.5194/angeo27-2869-2009, 2009.

Farahat, A.: Air Pollution in Arabian Peninsula (Saudi Arabia, United Arab Emirates, Kuwait, Qatar, Bahrain, and Oman): Causes, Effects and Aerosol Categorization, Arab. J. Geosci., 9, 196, https://doi.org/10.1007/s12517-015-2203-y, 2016.

Farahat, A., El-Askary, H., and Al-Shaibani, A.: Study of Aerosols' Characteristics and Dynamics over the Kingdom of Saudi Arabia using a Multi Sensor Approach Combined with Ground Observations, Adv. Meteorol., 2015, 247531, https://doi.org/10.1155/2015/247531, 2015.

Farahat, A., El-Askary, H., and Dogan, A. U.: Aerosols size distribution characteristics and role of precipitation during dust storm formation over Saudi Arabia, Aerosol Air Qual. Res., 16, 25232534, https://doi.org/10.4209/aaqr.2015.11.0656, 2016a.

Farahat, A., El-Askary, H., Adetokunbo, P., and Fuad, A.-T.: Analysis of aerosol absorption properties and transport over North Africa and the Middle East using AERONET data, Ann. Geophys., 34, 1031-1044, https://doi.org/10.5194/angeo-34-10312016, 2016 b. 
Ginoux, P., Chin, M., Tegen, I., Prospero, J., Holben, B., Dubovik, O., and Lin, S.-J.: Sources and global distributions of dust aerosols simulated with the GOCART model, J. Geophys. Res., 106, 20255-20273, https://doi.org/10.1029/2000JD000053, 2001.

He, Q., Li, C., Tang, X., Li, H., Geng, F., and Wu, Y.: Validation of MODIS derived aerosol optical depth over the Yangtze River Delta in China, Remote Sens. Environ., 114, w21649, https://doi.org/10.1016/j.rse.2010.02.015, 2010.

Higurashi, A. and Nakjima, T.: Development of a two-channel aerosol retrieval algorithm on a global scale using NOAA AVHRR, J. Atmos. Sci., $\quad 56, \quad 924-941, \quad$ https://doi.org/10.1175/15200469(1999)056<0924:DOATCA>2.0.CO;2, 1999.

Hoell, A., Funk, C., and Barlow, M.: The regional forcing of Northern Hemisphere drought during recent warm tropical west Pacific Ocean La Niña events, Clim. Dynam., 42, 3289-3311, https://doi.org/10.1007/s00382-013-1799-4, 2013.

Holben, B., Eck, T., Slutsker, I., Tanré, D., Buis, J.,Setzer, A., Vermote, E., Reagan, J., Kaufman, Y., Nakajima, T., Lavenu, F., Jankowiak, I., and Smirnov, A.: AERONET - A federated instrument network and data archive for aerosol characterization, Remote Sens. Environ., 66, 1-16, 1998.

Holben, B., Tanre, D., Smirnov, A., Eck, T., Slutsker, I., Abuhassan, N., Newcomb, W., Schafer, J., Chatenet, B., Lavenu, F., Kaufman, Y., Castle, J., Setzer, A., Markham, B., Clark, D., Frouin, R., Halthore, R., Karneli, A., O’Neill, N., Pietras, C., Pinker, R., Voss, K., and Zibordi, G.: An emerging ground-based aerosol climatology - Aerosol optical depth from AERONET, J. Geophys Res., 106, 12067-12097, 2001.

Hsu, N. C., Gautam, R., Sayer, A. M., Bettenhausen, C., Li, C., Jeong, M. J., Tsay, S.-C., and Holben, B. N.: Global and regional trends of aerosol optical depth over land and ocean using SeaWiFS measurements from 1997 to 2010, Atmos. Chem. Phys., 12, 8037-8053, https://doi.org/10.5194/acp-12-8037-2012, 2012.

Ichoku, C., Chu, D. A., Mattoo, S., Kaufman, Y. J., Remer, L. A., Tanre, D., Slutsker, I., and Holben, B. N.: A spatio-temporal approach for global validation and analysis of MODIS aerosol product, Geophys. Res. Lett., 29, 8006, https://doi.org/10.1029/2001GL013206, 2002.

Kahn, R. A., Gaitley, B. J., Martonchik, J. V., Diner, D. J., Crean, K. A., and Holben, B.: Multiangle ImagingSpectroradiometer (MISR) global aerosol optical depth validation based on 2 years of coincident Aerosol Robotic Network (AERONET) observations, J. Geophys. Res., 110, D10S04, https://doi.org/10.1029/2004JD004706, 2005.

Kahn, R., Garay, M., Nelson, D., Yau, K., Bull, M., Gaitley, B., Martonchik, J., and Levy, R. : Satellite-derived aerosol optical depth over dark water from MISR and MODIS: Comparisons with AERONET and implications for climatological studies, J. Geophys. Res., 112, D18205, https://doi.org/10.1029/2006JD008175, 2007.

Kahn, R., Nelson, David, L., Garay, M., Levy, R., Bull, M., Diner, D., Martonchik, J., Paradise, S., Hansen, E., and Remer, L.: MISR aerosol product attributes, and statistical comparisons with MODIS, IEEE T. Geosci. Remote, 47, 4095-114, https://doi.org/10.1109/TGRS.2009.2023115, 2009.

Kaufman, Y., Tanre, D., Remer, L., Vermote, E., Chu, A., and Holben, B.: Operational remote sensing of tropospheric aerosol over land from EOS moderate resolution imaging spectroradiometer, J. Geophys. Res.-Atmos., 102, 17051-17067, https://doi.org/10.1029/96JD03988, 1997.

Kim, D., Chin, M., Bian, H., Tan, Q., Brown, M. E., Zheng, T., You, R., Diehl, T., Ginoux, P., and Kucsera, T.: The effect of the dynamic surface bareness on dust source function, emission, and distribution, J. Geophys. Res., 118, 1-16, https://doi.org/10.1029/2012JD017907, 2013.

Kokhanovsky, A., Breon, F., Cacciari, A., Carboni, E., Diner, D.. Di Nicolantonio, W., Grainger, R., Grey, W., Höller, R., Lee, K., Li, Z., North, P., Sayer, A., Thomas, G., and Hoyningen-Huene, W.: Aerosol remote sensing over land: a comparison of satellite retrievals using different algorithms and instruments, Atmos Res., 85, 372-394, https://doi.org/10.1016/j.atmosres.2007.02.008, 2007.

Levy, R., Remer, L., Kleidman, R., Mattoo, S., Ichoku, C., Kahn, R., and Eck, T.: Global evaluation of the Collection 5 MODIS dark-target aerosol products over land, Atmos. Chem. Phys., 10, 10399-10420, https://doi.org/10.5194/acp-10-10399-2010, 2010.

Liu, L. and Mishchenko, M.: Toward unified satellite climatology of aerosol properties: direct comparisons of advanced level 2 aerosol products, J. Quant. Spectrosc. Ra., 109, 2376-2385, https://doi.org/10.1016/j.jqsrt.2008.05.003, 2008.

Marey, H., Gille, J., El-Askary, H., Shalaby, E., and El-Raey, M.: Study of the formation of the "black cloud" and its dynamics over Cairo, Egypt, using MODIS and MISR sensors, J. Geophys. Res., 115, D21206, https://doi.org/10.1029/2010JD014384, 2010.

Martonchik, J., Diner, D., Crean, K., and Bull, M.: Regional aerosol retrieval results from MISR, IEEE T. Geosci. Remote, 40, 15201531, https://doi.org/10.1109/TGRS.2002.801142, 2002.

Mishchenko, M., Geogdzhayev, I., Liu, L., Lacis, A., Cairns, B., and Travis, L.: Toward unified satellite climatology of aerosol properties: what do fully compatible MODIS and MISR aerosol pixels tell us?, J. Quant. Spectrosc. Ra., 110, 402-408, https://doi.org/10.1016/j.jqsrt.2009.01.007, 2009.

Mishchenko, M., Liu, L., Geogdzhayev, I., Travis, L., Cairns, B., and Lacis, A.: Toward unified satellite climatology of aerosol properties: 3. MODIS versus MISR versus AERONET, J. Quant. Spectrosc. Ra., 111, 540-552, https://doi.org/10.1016/j.jqsrt.2009.11.003, 2010.

Remer, L., Kaufman, Y., Tanré, D., Mattoo, S., Chu, D., Martins, J., Li, R., Ichoku, C., Levy, R., Kleidman, R., Eck, T., Vermote, E., and Holben, B.: The MODIS aerosol algorithm, products, and validation, J. Atmos. Sci., 62, 947-973, https://doi.org/10.1175/JAS3385.1, 2005.

Sadiq, M. and McCain, J.: The Gulf War Aftermath: An Environmental Tragedy, 1st Edn., Kluwer Academic Publisher, available at: https://www.springer.com/gp/book/9789401047371 (last access: January 2019), 1993.

Sayer, A. M., Hsu, N. C., Eck, T. F., Smirnov, A., and Holben, B. N.: AERONET-based models of smoke-dominated aerosol near source regions and transported over oceans, and implications for satellite retrievals of aerosol optical depth, Atmos. Chem. Phys., 14, 11493-11523, https://doi.org/10.5194/acp-14-114932014, 2014.

Schepanski, K., Mallet, M., Heinold, B., and Ulrich, M.: North African dust transport toward the western Mediterranean basin: atmospheric controls on dust source activation and trans- 
port pathways during June-July 2013, Atmos. Chem. Phys., 16, 14147-14168, https://doi.org/10.5194/acp-16-14147-2016, 2016.

Sioris, C. E., McLinden, C. A., Shephard, M. W., Fioletov, V. E., and Abboud, I.: Assessment of the aerosol optical depths measured by satellite-based passive remote sensors in the Alberta oil sands region, Atmos. Chem. Phys., 17, 1931-1943, https://doi.org/10.5194/acp-17-1931-2017, 2017.

Smirnov, A., Holben, B., Eck, T., Dubovik, O., and Slutsker, I.: Cloud-screening and quality control algorithms for the AERONET data-base, Remote Sens. Environ., 73, 337-349, https://doi.org/10.1016/S0034-4257(00)00109-7, 2000.

Solomos, S., Ansmann, A., Mamouri, R.-E., Binietoglou, I., Patlakas, P., Marinou, E., and Amiridis, V.: Remote sensing and modelling analysis of the extreme dust storm hitting the Middle East and eastern Mediterranean in September 2015, Atmos. Chem. Phys., 17, 4063-4079, https://doi.org/10.5194/acp17-4063-2017, 2017.

Todd, M., Washington, R., Vanderlei, M., Dubovik, O., Lizcano, G., M'Bainayel, S., and Engelstaedter, S.: Mineral dust emission from the Bodélé Depression, northern Chad, during BoDEx 2005, J. Geophys. Res., 112, D06207, https://doi.org/10.1029/2006JD007170, 2007.
Von Hoyningen-Huene, W. and Posse, P.: Nonsphericity of aerosol particles and their contribution to radiative forcing, J. Quant. Spectrosc. Ra., 57, 651-668, https://doi.org/10.1016/S00224073(96)00153-7, 1997.

Yu, Y., Notaro, M., Liu, Z., Kalashnikova, O., Alkolibi, F., Fadda, E., and Bakhrjy, F.: Assessing temporal and spatial variations in atmospheric dust over Saudi Arabia through satellite, radiometric, and station data, J. Geophys. Res.-Atmos., 118, 1325313264, https://doi.org/10.1002/2013JD020677, 2013.

Yu, Y., Notaro, M., Liu, Z., Wang, F., Alkolibi, F., Fadda, E., and Bakhrjy, F.: Climatic controls on the interannual to decadal variability in Saudi Arabian dust activity: Toward the development of a seasonal dust prediction model, J. Geophys. Res.-Atmos., 120, 1739-1758, https://doi.org/10.1002/2014JD022611, 2015.

Zhao, G. and Girolamo, L.: A cloud fraction versus view angle technique for automatic in-scene evaluation of the MISR cloud mask, J. Appl. Meteorol., 43, 860-869, https://doi.org/10.1175/15200450(2004)043<0860:ACFVVA>2.0.CO;2, 2004. 